\title{
EFFECT OF RICE BRAN OIL ADDITION ON THE OXIDATIVE DEGRADATION AND FATTY ACID COMPOSITION OF SOYBEAN OIL DURING HEATING
}

\author{
M. Abbas Ali ${ }^{1 凶}$, M. Azizul Islam¹, Noor Hidayu Othman², Ahmadilfitri Md Noor², \\ M. Ibrahim ${ }^{3}$ \\ ${ }^{1}$ Department of Chemistry, Rajshahi University of Engineering and Technology \\ Rajshahi 6204, Bangladesh \\ 2Department of Processing Technology, Oils and Fats, Sime Darby Research Sdn. Bhd. \\ Carey Island, Selangor, Malaysia \\ ${ }^{3}$ Fruits and Food Processing and Preservation Research Division, Bangladesh Council of Scientific and Industrial Research Labo- \\ ratories, Rajshahi 6206, Bangladesh
}

\begin{abstract}
Background. Rice bran oil (RBO) contains significant amounts of micronutrients (oryzanol, tocotrienol, tocopherol, phytosterols etc.) that impart a high resistance to thermal oxidation of the oil. The high oxidative stability of RBO can make it a preferred oil to improve the oxidative and flavor stabilities of other oils rich in PUFAs. In this study, the changes in the oxidative status and fatty acid composition in soybean oil (SO) blended with RBO under extreme thermal conditions were evaluated.

Material and methods. The blends were prepared in a volume ratio of 10:90, 20:80, 40:60, and 60:40 (RBO:SO). The changes in the oxidative parameters and fatty acid composition of the samples during heating at frying temperature $\left(170^{\circ} \mathrm{C}\right)$ were determined using analytical and instrumental methods. Oxidative alteration was also monitored by recording FTIR spectra of oil samples.

Results. The increase in oxidative parameters (free fatty acid, color, specific extinctions, peroxide value, $p$-anisidine value, and thiobarbituric acid value) was greater in pure $\mathrm{SO}$ as compared to $\mathrm{RBO}$ or blend oils during heating. This indicates that the SO samples incorporated with RBO have the least degradation, while pure SO has the highest. Blending resulted in a lower level of polyunsaturated fatty acids (PUFA) with a higher level of saturated fatty acids (SFA) and monounsaturated fatty acids (MUFA). During heating, the relative content of PUFA decreased and that of SFA increased. However, the presence of RBO in SO slowed down the oxidative deterioration of PUFA. In FTIR, the peak intensities in SO were markedly changed in comparison with blend oils during heating. The reduction in the formation of oxidative products in SO during thermal treatment increased as the concentration of the RBO in SO increased; however, the levels of the protective effect of RBO did not increase steadily with an increase in its concentration.

Conclusions. During thermal treatment, the generation of hydroperoxides, their degradation and formation of secondary oxidative products as evaluated by oxidative indices, fatty acids and IR absorbances were lower in blend oils compared to pure SO. In conclusion, RBO can significantly retard the process of lipid peroxidation in SO during heating at frying temperature.
\end{abstract}

Keywords: oxidative indices, thermal stability, blend oil, thermal treatment, infrared spectra 


\section{INTRODUCTION}

Rice bran oil (RBO) is obtained from rice husk, a byproduct of the rice milling industry. It contains appreciable quantities of bioactive components and has attained the status of a "heart oil" due to its cardiacfriendly chemical profile (Sohail et al., 2017). Rice bran oil - RBO contains a unique component - gamma-oryzanol, and high levels of phytosterols and tocols (Das et al., 2018; Perez-Ternero et al., 2017). Taking advantage of the micronutrients present in $\mathrm{RBO}$, it was considered that the value of other edible oils could be nutritionally improved by blending with RBO. In addition, these naturally occurring components impart a high resistance to the thermal oxidation and deterioration of the oil. The high oxidative stability of RBO makes it a preferred oil for frying and baking applications (Semwal and Arya, 2001). Choudhary et al. (2015) stated that blending of non-conventional RBO with traditional oils (sunflower oil, canola oil etc.) can result in a stable cooking oil that reduces the demand for traditional oils. On the other hand, soybean oil is widely used in cooking and frying processes. It is rich in unsaturated fatty acids, including about $23 \%$ MUFA and 58\% PUFA, which are highly prone to oxidation (Ivanov et al., 2010). To improve the oxidative stability during heating/frying process, the use of fats/oils with low unsaturation is suitable, because the oxidation rate of these oils is much lower than the oils with a high PUFA. The fatty acid profile of the oils is basically the factor responsible for oxidation, and also the formation of undesirable compounds/flavors (Arslan et al., 2015; Fernández-Cedi et al., 2012). Rudzińska et al. (2018) stated that SO is extremely liable to oxidate during the frying process. However, a wide range of vegetable oils are available on the market, but some vegetable oils are not up to standards to meet consumer satisfaction in terms of their stability (Mostafa et al., 2013). During a prolonged exposure to high temperatures, stability to oxidation is one of the main characteristics of that frying oil should possess, because its physico-chemical and nutritional properties may undergo significant modifications during heating (De Marco et al., 2007). However, there is global demand for the production of a blend oil for culinary uses, because of improved thermal stability, nutritional benefits, cheaper alternatives or substitutes to pure vegetable oils (Ali et al., 2014; Srivastava et al., 2017).

Oxidation in oils and fats takes place at the double bond sites in the triacyleglycerol molecules (Ribeiro et al., 2007). The oxidative stability of an oil depends on its fatty acid and triacylglycerol compositions, and the composition of minor components with antioxidant capacity (Nederal et al., 2012). Monitoring the changes in the fatty acid composition of oils during heating is an effective method to examine thermal oxidation changes in the oils. The effects of thermal treatments on the oxidative degradation and physico-chemical properties of some vegetable oils as affected by added RBO have been reported elsewhere (Mishra and Sharma, 2014; Rudzińska et al., 2016; Sharma et al., 2006). Very few studies have reported on the oxidative changes and fatty acid composition of SO incorporated with RBO under adverse thermal conditions, and this is the main objective of the present study.

\section{MATERIAL AND METHODS}

\section{Sample and reagent}

Freshly milled rice bran was obtained from a direct milling system (Osman Agro Industries, Naogaon) in airtight polyethylene bags. Refined, bleached and deodorized SO with no added antioxidants was collected from a local oil mill (Jamuna Edible Oil Mill, Rajshahi). Thioburbituric acid was produced by HiMedia Laboratories (Mumbai, India), while acetic acid and standards were from Sigma-Aldrich Co. (St. Louis, MO, USA). Analytical-grade solvents and other chemicals were produced by Merck (Darmstadt, Germany or Mumbai, India).

\section{Oil sample preparation}

Rice bran was adjusted moisture level to $21 \%$ (Lakkakula et al., 2004) and endogenous lipase of the bran was inactivated by means of a microwave ( 2450 $\mathrm{MHz}$, output power $850 \mathrm{~W}$ ) for $3 \mathrm{~min}$. The oil was extracted from the stabilized rice bran using n-hexane at a solid-to-solvent ratio of 1:10 (w/v) using a magnetic stirrer for $3 \mathrm{~h}$. The extract was filtered and the residue was re-extracted twice with the same solvent. The filtrates were combined and dried at $45^{\circ} \mathrm{C}$ under a vacuum using a rotary evaporator (Rotavapor R-210, Buchi Labortechnik AG, Switzerland). The chemical 
refining process of crude $\mathrm{RBO}$ was conducted using the conventional method (Mezouari and Eichner, 2007; Pestana et al., 2008). The crude oil (500 mL) was heated to $72^{\circ} \mathrm{C}$ and degummed by adding water with slow agitation for $30 \mathrm{~min}$. Next, the oil was settled for $30 \mathrm{~min}$ and the water with dissolved gum was drained out. The degummed oil was heated to $80^{\circ} \mathrm{C}$ and the required amount of $\mathrm{NaOH}(1 \%, w / w)$ was added. It was then stirred and left to react for $30 \mathrm{~min}$ at room temperature. The soap stock was separated from the neutralized oil by decantation and centrifugation. The oil was washed three times with water. The neutralized oil was brought to $90^{\circ} \mathrm{C}$ under a vacuum and $1 \%(\mathrm{w} / \mathrm{w})$ of bleaching earth was added. Once this temperature was reached, the oil was stirred for 30 $\mathrm{min}$, cooled to room temperature and filtered through filter paper. The oil was then cooled gradually at $12^{\circ} \mathrm{C}$ for $4 \mathrm{~h}$ for crystallization of wax and filtered to remove the wax. Deodorization was carried out under a vacuum at $245^{\circ} \mathrm{C}$ for $2 \mathrm{~h}$ using nitrogen as a stripping gas. The $\mathrm{SO}$ was blended with a refined RBO in varying proportions. The RBO:SO $(\mathrm{v} / \mathrm{v})$ blends were prepared as following: 10:90, 20:80, 40:60, and 60:40. The mixtures were stirred in a magnetic stirrer for 20 min for homogenization.

\section{Heating and oil sampling}

The pure and blend oil samples $(70 \mathrm{~g})$ were put into $100 \mathrm{~mL}$ beakers and placed in an electric oven (model 28 , Binder $\mathrm{GmbH}$, Germany) at $170 \pm 2^{\circ} \mathrm{C}$ in order to accelerate the lipid oxidation and thermal degradation. The oil samples were collected at intervals of $0,4,8$, and $12 \mathrm{~h}$ for analysis.

\section{Fatty acid composition (FAC)}

Triacylglycerols were transesterified to convert them into fatty acid methyl esters, according to the PORIM (1995) method p3.4 and were analyzed by a gas chromatograph (7890A, Agilent Technologies, USA) equipped with a polar $\mathrm{SP}^{\mathrm{TM}}$ (Supelco, Bellefonte, $\mathrm{PA}$ ) capillary column $(0.25 \mathrm{~mm}$ i.d $\times 60 \mathrm{~m} \times 0.2 \mu \mathrm{m})$ and a flame ionization detector. Nitrogen at a flow rate of $20 \mathrm{~mL} / \mathrm{min}$ was used as carrier gas. The column oven was heated to $100^{\circ} \mathrm{C}$ and raised to $250^{\circ} \mathrm{C}$ at the rate of $10^{\circ} \mathrm{C}$ per min. Methyl esters were quantified by comparing the retention times and peak area of the unknowns with known FAME standards.

\section{Oxidative indices}

Standard methods of AOCS (1987) were used to determine the following: free fatty acid content (method $\mathrm{Ca}$ 5a-40), peroxide value (method Cd 8-53), and thiobarbituric acid value (method Cd 19-90). Determination of $p$-anisidine value (method $\mathrm{p} 2.4$ ) and specific extinctions (method p2.15) at 233 and $269 \mathrm{~nm}\left(\mathrm{E}^{1 \%}{ }_{233}\right.$ and $\mathrm{E}^{1 \%}{ }_{269}$, respectively) of the samples was carried out by means of a Spectrophotometer (T 60, PG Instruments, Leicestershire, UK) according to the PORIM (1995) test methods. Total oxidation value was derived using the Holm's equation: TOTOX $=2 \mathrm{PV}+p$-AV (Wai et al., 2009). For determining colour development, the absorbance at $420 \mathrm{~nm}$ of $5.0 \%(\mathrm{w} / \mathrm{v})$ solutions of oils in chloroform was measured using a spectrophotometer ( $\mathrm{T}$ 60U, PG Instruments, Leicestershire, UK) (Yoshida et al., 1999).

\section{FT-IR spectroscopy}

The infrared spectra of oil samples were measured using a Fourier Transform Infrared (FTIR) Spectroscopy (IRAffinity-1S, Shimadzu Corporation, Kyoto, Japan) furnished with a high-sensitivity pyroelectric detector (deuterated L-alanine doped triglycine sulphate). The spectra were collected with a spectral resolution of $2 \mathrm{~cm}^{-1}$ and a frequency range from 4000 to $850 \mathrm{~cm}^{-1}$.

\section{Statistical analysis}

All analyses were performed in triplicate unless otherwise stated. The results were made as mean \pm standard deviation (SD) and were subjected to one-way analysis of variance (ANOVA). Mean values were compared at a $p<0.05$ significant level by Duncan's multiple range test using IBM SPSS 22 statistics.

\section{RESULTS AND DISCUSSION}

\section{Changes in the fatty acid composition of pure and blend oils}

Some food-processing techniques can affect the fatty acid composition of oils when hardly subjected to successive heating (Lee et al., 2007). The fatty acid composition (FAC) of oil can be an indicator of its stability, physical properties and nutritional value. Table 1 shows the FAC of RBO, SO and their binary blends. SO had the highest level of linoleic acid $(52.51 \%)$, followed by oleic $(25.29 \%)$ and palmitic $(10.55 \%)$ acids. 
However, in RBO, the major fatty acid was oleic acid $(41.19 \%)$, followed by linoleic $(34.16 \%)$ and palmitic $(18.30 \%)$ acids. These results are consistent with the values for the same sample reported by Chotimarkorn and Silalai (2008). The sample SO incorporated with different amounts of RBO led to a change in the FAC that occurred progressively as a function of the percentage of RBO in the blend. When increasing the percentage of RBO from 10 to 60 , the amounts of palmitic and oleic acids also increased, followed by a decrease in linoleic acid. As shown in Table 1, the blend of SO with RBO caused a significant $(p<0.05)$ increase in the content of MUFA and SFA, in parallel with a significant decrease in the levels of PUFA. The FAC of frying oil greatly influences its oxidative stability. SO contains higher PUFA (57.41\%) compared to that of RBO (36.47\%). Shahidi (2005) reported that the higher content of PUFA results in lower oxidative stability. In SO without added RBO, the relative content of PUFA was rapidly decreased to $83.40 \%$, while that of SFA was increased to $116.58 \%$ after $12 \mathrm{~h}$ of heating (Table 2). There was a slow decrease in the relative content of PUFA in SO containing 10, 20 and $40 \%$ of RBO to $84.88,85.83$ and $88.54 \%$, respective$\mathrm{ly}$, at the end of heating. On the other hand, the relative content of SFA in SO containing 10, 20 and $40 \%$ of RBO increased to $118.45,111.61$ and $108.90 \%$, respectively, at the same time of heating. In addition, MUFA also increased accordingly in most cases. The present results reveal that the amount of RBO incorporated with SO affected the changes of FAC during thermal oxidation; this probably provided protection to SO against lipid oxidation during heating. Blending SO with $\mathrm{RBO}$ caused a decrease in the ratio of linoleic acid to palmitic acid $\left(\mathrm{C}_{18: 2} / \mathrm{C}_{16: 0}\right)$. The initial value of the $\mathrm{C}_{18: 2} / \mathrm{C}_{16: 0}$ ratio was lower in the blends than in $\mathrm{SO}$ due to the addition of more saturated RBO. The ratio $C_{18: 2} / C_{16: 0}$ has been suggested as a valid indicator of the level of PUFA deterioration (Normand et al., 2001). In this work, this ratio decreased in all oil samples during heating. The highest decreased amount from the initial was found in SO (1.68 unit), followed by blends (0.69-1.57 unit) with the least in RBO $(0.30$ unit). The present results revealed that adding RBO

Table 1. Fatty acid composition of rice bran oil, soybean oil, and their blends before heating, $\%$

\begin{tabular}{|c|c|c|c|c|c|}
\hline \multirow{3}{*}{ Fatty acids } & \multicolumn{5}{|c|}{ Oil sample } \\
\hline & \multirow{2}{*}{$\mathrm{RBO}$} & \multirow{2}{*}{$\mathrm{SO}$} & \multicolumn{3}{|c|}{ Blend (RBO:SO) } \\
\hline & & & $10: 90$ & $20: 80$ & $40: 60$ \\
\hline Myristic acid (C14:0) & $0.31 \pm 0.01^{\mathrm{c}}$ & $0.08 \pm 0.00^{\mathrm{a}}$ & $0.10 \pm 0.01^{\mathrm{a}}$ & $0.14 \pm 0.01^{\mathrm{b}}$ & $0.15 \pm 0.00^{\mathrm{b}}$ \\
\hline Palmitic acid (C16:0) & $18.30 \pm 0.07^{\mathrm{d}}$ & $10.55 \pm 0.50^{\mathrm{a}}$ & $11.15 \pm 0.40^{\mathrm{a}}$ & $12.71 \pm 0.14^{\mathrm{b}}$ & $14.34 \pm 0.15^{\mathrm{c}}$ \\
\hline Palmitoleic acid (C16:1) & $0.20 \pm 0.01^{\mathrm{b}}$ & $0.09 \pm 0.00^{\mathrm{a}}$ & $0.10 \pm 0.00^{\mathrm{a}}$ & $0.13 \pm 0.01^{\mathrm{a}}$ & $0.12 \pm 0.00^{\mathrm{a}}$ \\
\hline Stearic acid (C18:0) & $2.41 \pm 0.02^{\mathrm{a}}$ & $4.05 \pm 0.05^{\mathrm{c}}$ & $4.04 \pm 0.04^{\mathrm{c}}$ & $3.82 \pm 0.03^{b}$ & $4.47 \pm 0.02^{\mathrm{c}}$ \\
\hline Oleic acid (C18:1) & $41.19 \pm 0.12^{\mathrm{d}}$ & $25.29 \pm 0.25^{\mathrm{a}}$ & $25.22 \pm 0.09^{\mathrm{a}}$ & $27.81 \pm 0.15^{\mathrm{b}}$ & $30.89 \pm 0.2^{\mathrm{c}}$ \\
\hline Linoleic acid (C18:2) & $34.16 \pm 0.04^{\mathrm{a}}$ & $52.51 \pm 0.19^{d}$ & $52.04 \pm 0.47^{\mathrm{d}}$ & $48.86 \pm 0.11^{\mathrm{c}}$ & $44.67 \pm 0.05^{\mathrm{b}}$ \\
\hline Linolenic acid (C18:3) & $2.31 \pm 0.02^{\mathrm{a}}$ & $4.89 \pm 0.05^{\mathrm{d}}$ & $4.90 \pm 0.09^{\mathrm{d}}$ & $4.36 \pm 0.04^{\mathrm{c}}$ & $3.34 \pm 0.02^{\mathrm{b}}$ \\
\hline Arachidic acid (C20:0) & $1.00 \pm 0.03^{\mathrm{c}}$ & $0.53 \pm 0.05^{\mathrm{a}}$ & $0.44 \pm 0.01^{\mathrm{a}}$ & $0.48 \pm 0.02^{\mathrm{a}}$ & $0.69 \pm 0.01^{\mathrm{b}}$ \\
\hline$\sum$ Saturated fatty acids & 22.02 & 15.20 & 15.72 & 17.14 & 19.65 \\
\hline$\sum$ Monounsaturated fatty acids & 41.38 & 25.38 & 25.32 & 27.94 & 31.01 \\
\hline$\sum$ Polyunsaturated fatty acids & 36.47 & 57.41 & 56.94 & 53.22 & 48.01 \\
\hline
\end{tabular}

Each value is the mean \pm standard deviation of triplicate determinations. Values with different letters within a row for each fatty acids were significantly different $(p<0.05)$. 
Ali, M. A., Islam, M. A., Othman, N. H., Noor, A. M., Ibrahim, M. (2019). Effect of rice bran oil addition on the oxidative degradation and fatty acid composition of soybean oil during heating. Acta Sci. Pol. Technol. Aliment., 18(4), 427-438. http://dx.doi.org/10.17306/ J.AFS.2019.0964

Table 2. Changes in saturated, monounsaturated, and polyunsaturated fatty acids of rice bran oil, soybean oil, and their blends during heating at $170^{\circ} \mathrm{C}$

\begin{tabular}{|c|c|c|c|c|c|c|}
\hline \multicolumn{2}{|c|}{ Sample } & $\begin{array}{c}\text { Heating time } \\
\mathrm{h}\end{array}$ & SFA & MUFA & PUFA & $\mathrm{C}_{18: 2} / \mathrm{C}_{16: 0}$ \\
\hline \multicolumn{2}{|c|}{$\mathrm{RBO}$} & 0 & $22.02(100)$ & $41.38(100)$ & $36.47(100)$ & 1.87 \\
\hline \multirow{7}{*}{ SO } & & 4 & $22.22(100.91)$ & $42.54(102.80)$ & $35.14(96.35)$ & 1.76 \\
\hline & & 8 & $23.52(106.81)$ & $42.33(102.29)$ & $33.94(93.06)$ & 1.63 \\
\hline & & 12 & $23.51(106.76)$ & $43.76(105.75)$ & $32.51(89.14)$ & 1.57 \\
\hline & & 0 & $15.20(100)$ & $25.38(100)$ & $57.41(100)$ & 4.98 \\
\hline & & 4 & $17.19(113.09)$ & $29.00(114.26)$ & $52.24(90.99)$ & 3.82 \\
\hline & & 8 & $17.66(116.18)$ & $30.43(119.90)$ & $50.49(87.95)$ & 3.52 \\
\hline & & 12 & $17.72(116.58)$ & 33.24 (130.97) & $47.88(83.40)$ & 3.30 \\
\hline \multirow{11}{*}{ 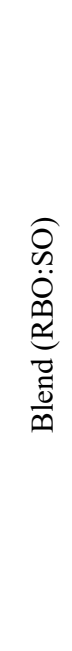 } & $10: 90$ & 0 & $15.72(100)$ & $25.32(100)$ & $56.94(100)$ & 4.67 \\
\hline & & 4 & $17.14(109.03)$ & 28.35 (111.96) & $52.87(92.85)$ & 3.80 \\
\hline & & 8 & $18.42(117.17)$ & $28.66(113.19)$ & $51.57(90.57)$ & 3.65 \\
\hline & & 12 & $18.62(118.45)$ & $31.84(125.75)$ & $48.33(84.88)$ & 3.10 \\
\hline & $20: 80$ & 0 & $17.14(100)$ & $27.94(100)$ & $53.22(100)$ & 3.84 \\
\hline & & 4 & $18.37(107.18)$ & $30.63(109.63)$ & $49.63(93.25)$ & 3.42 \\
\hline & & 12 & $19.13(111.61)$ & $34.12(122.12)$ & $45.68(85.83)$ & 2.91 \\
\hline & $40: 60$ & 0 & $19.65(100)$ & $31.01(100)$ & $48.01(100)$ & 3.11 \\
\hline & & 4 & $20.87(106.21)$ & $32.19(103.80)$ & $45.35(94.45)$ & 2.76 \\
\hline & & 8 & $19.70(100.25)$ & $35.24(113.64)$ & $44.25(92.17)$ & 2.59 \\
\hline & & 12 & $21.40(108.90)$ & $34.52(111.32)$ & $42.51(88.54)$ & 2.42 \\
\hline
\end{tabular}

The numbers in parenthesis are the relative \% of saturated (SFA), monounsaturated (MUFA) and polyunsaturated (PUFA) fatty acids based on the initial saturated, monounsaturated and polyunsaturated fatty acids content before thermal oxidation. $\mathrm{C}_{18: 2} / \mathrm{C}_{16: 0}-$ ratio of linoleic acid to palmitic acid. Each value is the mean of triplicate determinations.

to SO prevented the breakdown of the PUFA of SO. These results were in agreement with the findings of Ali et al. (2014), who revealed that adding palm olein (PO) to sunflower oil (SFO) slowed down the rate of degradation of PUFA of SFO during deep fat frying of potato pieces at $185 \pm 5^{\circ} \mathrm{C}$.

\section{Changes in oxidative indices}

The free fatty acid (FFA) content of all edible oils increased significantly $(p<0.05)$ and steadily during heating at $170^{\circ} \mathrm{C}$ (Table 3). The amount of FFA increases as a result of the hydrolysis of triacylglycerols, which contributes to the development of off-flavours and offodours in the oil (Rohman et al., 2011). During heating, the lowest and highest changes in FFA amounts were detected in the RBO (from 0.16 to $0.65 \%$ ) and SO (from 0.11 to $0.86 \%$ ), respectively. However, partial replacement of SO with RBO could result in decreased FFA during heating, which indicates that the rate of generation of FFA was faster in pure SO compared to that in blend oils. The absorbance values of pure and blend oils as an index for colour development in the 
Ali, M. A., Islam, M. A., Othman, N. H., Noor, A. M., Ibrahim, M. (2019). Effect of rice bran oil addition on the oxidative degradation and fatty acid composition of soybean oil during heating. Acta Sci. Pol. Technol. Aliment., 18(4), 427-438. http://dx.doi.org/10.17306/ J.AFS.2019.0964

Table 3. Changes in free fatty acid content, colour (absorbance at $420 \mathrm{~nm}$ ) and specific extinction value of rice bran oil, soybean oil, and their blends during heating

\begin{tabular}{|c|c|c|c|c|c|c|c|}
\hline \multirow{2}{*}{ Parameter } & \multirow{2}{*}{$\begin{array}{l}\text { Heating } \\
\text { time } \\
\mathrm{h}\end{array}$} & \multicolumn{2}{|c|}{ Control } & \multicolumn{4}{|c|}{ Blend (RBO:SO) } \\
\hline & & $\mathrm{RBO}$ & SO & $10: 90$ & $20: 80$ & $40: 60$ & $60: 40$ \\
\hline \multirow[t]{4}{*}{ FFA, \% } & 0 & $0.16 \pm 0.01^{\mathrm{bA}}$ & $0.11 \pm 0.01^{\mathrm{aA}}$ & $0.11 \pm 0.01^{\mathrm{aA}}$ & $0.12 \pm 0.02^{\mathrm{aA}}$ & $0.12 \pm 0.01^{\mathrm{aA}}$ & $0.13 \pm 0.03^{\mathrm{aA}}$ \\
\hline & 4 & $0.34 \pm 0.02^{\mathrm{aB}}$ & $0.38 \pm 0.06^{\mathrm{aB}}$ & $0.37 \pm 0.02^{\mathrm{aB}}$ & $0.37 \pm 0.06^{\mathrm{aB}}$ & $0.36 \pm 0.03^{\mathrm{aB}}$ & $0.34 \pm 0.03^{\mathrm{aB}}$ \\
\hline & 8 & $0.47 \pm 0.09^{\mathrm{aC}}$ & $0.59 \pm 0.08^{\mathrm{aC}}$ & $0.55 \pm 0.07^{\mathrm{aC}}$ & $0.52 \pm 0.05^{\mathrm{aC}}$ & $0.49 \pm 0.03^{\mathrm{aC}}$ & $0.48 \pm 0.05^{\mathrm{aC}}$ \\
\hline & 12 & $0.65 \pm 0.02^{\mathrm{aD}}$ & $0.86 \pm 0.04^{\mathrm{dD}}$ & $0.81 \pm 0.09^{\mathrm{cdD}}$ & $0.77 \pm 0.07^{\mathrm{bcdD}}$ & $0.72 \pm 0.05^{\mathrm{abcD}}$ & $0.68 \pm 0.06^{\mathrm{abD}}$ \\
\hline \multirow{4}{*}{$\begin{array}{l}\text { Absorb- } \\
\text { ance at } 420 \\
\mathrm{~nm}\end{array}$} & 0 & $0.20 \pm 0.02^{\mathrm{aA}}$ & $0.18 \pm 0.03^{\mathrm{aA}}$ & $0.18 \pm 0.02^{\mathrm{aA}}$ & $0.19 \pm 0.01^{\mathrm{aA}}$ & $0.19 \pm 0.02^{\mathrm{aA}}$ & $0.19 \pm 0.04^{\mathrm{aA}}$ \\
\hline & 4 & $0.38 \pm 0.04^{\mathrm{aB}}$ & $0.45 \pm 0.02^{\mathrm{aB}}$ & $0.43 \pm 0.05^{\mathrm{aB}}$ & $0.42 \pm 0.04^{\mathrm{aB}}$ & $0.41 \pm 0.02^{\mathrm{aB}}$ & $0.40 \pm 0.04^{\mathrm{aB}}$ \\
\hline & 8 & $0.59 \pm 0.08^{\mathrm{aC}}$ & $0.74 \pm 0.03^{\mathrm{bC}}$ & $0.71 \pm 0.04^{\mathrm{bC}}$ & $0.69 \pm 0.04^{\mathrm{bC}}$ & $0.68 \pm 0.03^{\mathrm{bC}}$ & $0.66 \pm 0.05^{\mathrm{bC}}$ \\
\hline & 12 & $0.77 \pm 0.03^{\mathrm{aD}}$ & $0.98 \pm 0.05^{\mathrm{bD}}$ & $0.95 \pm 0.07^{\mathrm{bD}}$ & $0.93 \pm 0.04^{\mathrm{bD}}$ & $0.90 \pm 0.05^{\mathrm{bD}}$ & $0.87 \pm 0.10^{\mathrm{bD}}$ \\
\hline \multirow[t]{4}{*}{$\mathrm{E}^{1 \%}{ }_{233}$} & 0 & $2.60 \pm 0.02^{\mathrm{aA}}$ & $2.65 \pm 0.02^{\mathrm{aA}}$ & $2.65 \pm 0.05^{\mathrm{aA}}$ & $2.64 \pm 0.03^{\mathrm{aA}}$ & $2.64 \pm 0.06^{\mathrm{aA}}$ & $2.62 \pm 0.05^{\mathrm{aA}}$ \\
\hline & 4 & $2.89 \pm 0.03^{\mathrm{aB}}$ & $4.68 \pm 0.05^{\mathrm{fB}}$ & $3.93 \pm 0.03^{\mathrm{eB}}$ & $3.60 \pm 0.06^{\mathrm{dB}}$ & $3.12 \pm 0.04^{\mathrm{bB}}$ & $3.28 \pm 0.04^{\mathrm{cB}}$ \\
\hline & 8 & $3.82 \pm 0.05^{\mathrm{aC}}$ & $6.82 \pm 0.09^{\mathrm{fC}}$ & $6.26 \pm 0.04^{\mathrm{eC}}$ & $6.00 \pm 0.02^{\mathrm{dC}}$ & $5.30 \pm 0.02^{\mathrm{cC}}$ & $5.01 \pm 0.04^{\mathrm{bC}}$ \\
\hline & 12 & $4.96 \pm 0.04^{\mathrm{aD}}$ & $8.99 \pm 0.12^{\mathrm{fD}}$ & $8.00 \pm 0.08^{\mathrm{eD}}$ & $7.23 \pm 0.06^{\mathrm{dD}}$ & $6.37 \pm 0.03^{\mathrm{cD}}$ & $6.12 \pm 0.09^{\mathrm{bD}}$ \\
\hline \multirow[t]{4}{*}{$\mathrm{E}^{1 \%}{ }_{269}$} & 0 & $0.50 \pm 0.06^{\mathrm{aA}}$ & $0.58 \pm 0.04^{\mathrm{aA}}$ & $0.56 \pm 0.02^{\mathrm{aA}}$ & $0.56 \pm 0.03^{\mathrm{aA}}$ & $0.55 \pm 0.05^{\mathrm{aA}}$ & $0.55 \pm 0.01^{\mathrm{aA}}$ \\
\hline & 4 & $0.63 \pm 0.02^{\mathrm{aB}}$ & $0.95 \pm 0.04^{\mathrm{dB}}$ & $0.88 \pm 0.02^{\mathrm{cB}}$ & $0.83 \pm 0.02^{\mathrm{cB}}$ & $0.77 \pm 0.06^{\mathrm{bB}}$ & $0.76 \pm 0.02^{\mathrm{bB}}$ \\
\hline & 8 & $0.80 \pm 0.02^{\mathrm{aC}}$ & $1.71 \pm 0.03^{\mathrm{eC}}$ & $1.67 \pm 0.03^{\mathrm{dC}}$ & $1.56 \pm 0.03^{\mathrm{dC}}$ & $1.30 \pm 0.07^{\mathrm{cC}}$ & $1.18 \pm 0.04^{\mathrm{bC}}$ \\
\hline & 12 & $1.00 \pm 0.04^{\mathrm{aD}}$ & $2.37 \pm 0.02^{\mathrm{eD}}$ & $2.20 \pm 0.09^{\mathrm{dD}}$ & $1.99 \pm 0.04^{\mathrm{dD}}$ & $1.76 \pm 0.07^{\mathrm{cD}}$ & $1.61 \pm 0.02^{\mathrm{bD}}$ \\
\hline
\end{tabular}

Results are expressed as means \pm standard deviations of triplicate determinations. Values with different letters (lowercase) within a row for each parameter were significantly different $(p<0.05)$. Values with different letters (uppercase) within a column for each parameter were significantly different $(p<0.05)$.

products are shown in Table 3 . The absorbance at 420 $\mathrm{nm}$ of the samples increased significantly $(p<0.05)$ during thermal treatment. As heating continued for a longer duration to $12 \mathrm{~h}$, the oil darkened because of the degradation processes, such as the formation of hydroperoxides, ketones, hydroxides of unsaturated fatty acid (Shao et al., 2015). A sharp increase in the absorbance value was noted in substrate oil SO $(0.18-0.98)$ and lowest detected in RBO $(0.20-0.77)$ during heating. The addition of RBO to SO decelerated the increment of absorbance value in blend oils and the lowest was detected in the RBO/SO (60:40) blend during heating compared to other blends. Ali et al. (2013) stated that adding palm olein (PO) to canola oil (CO) resulted in unexpected higher color units in the blends as compared to pure $\mathrm{CO}$ at the end of the frying process, which could not be explained easily by the marked differences in FA composition between PO and $\mathrm{CO}$. Higher initial values of PO could contribute to the darkness of $\mathrm{CO}$ during frying. The process of forming peroxides is concurrent with the conjugation of double bonds in PUFA, which can be measured using the specific absorptivity of conjugated dienes and trienes at 233 and $269 \mathrm{~nm}\left(\mathrm{E}^{1 \%}{ }_{233}\right.$ and $\left.\mathrm{E}^{1 \%}{ }_{269}\right)$ in the UV spectrum (Rohman et al., 2011). In the present investigations, the initially specific absorbtivity $\mathrm{E}^{1 \%}{ }_{233}$ and $\mathrm{E}^{1 \%}{ }_{269}$ of the SO sample was 2.65 and 0.58 , which increased up to 8.99 and 2.37, respectively, after $12 \mathrm{~h}$ of continuous heating (Table 3). The lower levels of both conjugated dienes and trienes shown in the blends are 
Ali, M. A., Islam, M. A., Othman, N. H., Noor, A. M., Ibrahim, M. (2019). Effect of rice bran oil addition on the oxidative degradation and fatty acid composition of soybean oil during heating. Acta Sci. Pol. Technol. Aliment., 18(4), 427-438. http://dx.doi.org/10.17306/ J.AFS.2019.0964

indications of the oil's good oxidative stability, and it is because of the lower percentage of PUFA content. The higher the percentage of PUFA in the oil, the higher the levels of conjugated dienes and trienes formed during heating (Abdulkarim et al., 2007). This was the reason why SO that contained high percentages of PUFA, accumulated more conjugated dienes and trienes. It was found from the present study that the levels of conjugated dienes are higher than trienes; this is indicated by the higher values specific absorbitivity at $232 \mathrm{~nm}$. A similar observation was noted by Srivastava and Semwal (2015) in the case of virgin coconut oil (VCO) during a continuous/prolonged deep fat frying process. However, adding RBO to the SO decelerated conjugated diene and triene formation in SO.

Peroxide value (PV) is used as a measure of the primary oxidation of oil, fat and fatty food. The PVs of the SOs as influenced by the RBO over $12 \mathrm{~h}$ heating are shown in Table 4. There was an initial sharp increase in the PV from 0 to $8 \mathrm{~h}$, after which the rate slowed down. SO incorporated with RBO displayed a slower rate of increment of PV compared to blends. This could be attributed to the high amounts of linoleic acids present in the SO compared to RBO. Ali et al. (2013) also followed a similar trend for palm olein/ canola oil blends while frying potato pieces at $185^{\circ} \mathrm{C}$. Peak values were attained as follows: RBO (12.14),

Table 4. Changes in peroxide value, $p$-anisidine value, TOTOX value and TBA value of rice bran oil, soybean oil, and their blends during heating

\begin{tabular}{|c|c|c|c|c|c|c|c|}
\hline \multirow{2}{*}{ Parameter } & \multirow{2}{*}{$\begin{array}{c}\text { Heating } \\
\text { time } \\
\mathrm{h}\end{array}$} & \multicolumn{2}{|c|}{ Control } & \multicolumn{4}{|c|}{ Blend (RBO:SO) } \\
\hline & & $\mathrm{RBO}$ & $\mathrm{SO}$ & $10: 90$ & $20: 80$ & $40: 60$ & $60: 40$ \\
\hline \multirow{4}{*}{$\begin{array}{l}\text { Peroxide } \\
\text { value } \\
\text { meq } \mathrm{O}_{2} / \mathrm{kg} \\
\text { of oil }\end{array}$} & 0 & $1.65 \pm 0.09^{\mathrm{aA}}$ & $2.02 \pm 0.06^{\mathrm{cA}}$ & $1.98 \pm 0.14^{\mathrm{cA}}$ & $1.90 \pm 0.06^{\mathrm{bcA}}$ & $1.87 \pm 0.07^{\mathrm{bcA}}$ & $1.80 \pm 0.09^{\mathrm{abA}}$ \\
\hline & 4 & $9.23 \pm 0.12^{\mathrm{aB}}$ & $16.78 \pm 0.10^{\mathrm{fB}}$ & $15.13 \pm 0.08^{\mathrm{eB}}$ & $13.45 \pm 0.12^{\mathrm{dB}}$ & $12.06 \pm 0.10^{\mathrm{cB}}$ & $11.11 \pm 0.12^{\mathrm{bB}}$ \\
\hline & 8 & $12.14 \pm 0.19^{\mathrm{aD}}$ & $25.39 \pm 1.02^{\mathrm{fD}}$ & $23.51 \pm 0.43^{\mathrm{eC}}$ & $21.91 \pm 0.68^{\mathrm{dD}}$ & $17.22 \pm 0.80^{\mathrm{cD}}$ & $15.77 \pm 0.72^{\mathrm{bD}}$ \\
\hline & 12 & $10.04 \pm 0.76^{\mathrm{aC}}$ & $17.98 \pm 0.51^{\mathrm{fC}}$ & $15.56 \pm 0.28^{\mathrm{eB}}$ & $14.51 \pm 0.20^{\mathrm{dC}}$ & $13.03 \pm 0.11^{\mathrm{cC}}$ & $12.00 \pm 0.13^{\mathrm{bC}}$ \\
\hline \multirow{4}{*}{$\begin{array}{l}p \text {-Anisidine } \\
\text { value }\end{array}$} & 0 & $4.10 \pm 0.04^{\mathrm{dA}}$ & $2.98 \pm 0.09^{\mathrm{aA}}$ & $3.10 \pm 0.06^{\mathrm{abA}}$ & $3.13 \pm 0.11^{\mathrm{abA}}$ & $3.25 \pm 0.16^{\mathrm{bA}}$ & $3.69 \pm 0.09^{\mathrm{cA}}$ \\
\hline & 4 & $19.19 \pm 0.17^{\mathrm{aB}}$ & $29.87 \pm 0.11^{\mathrm{eB}}$ & $28.93 \pm 0.22^{\mathrm{dB}}$ & $25.71 \pm 0.19^{\mathrm{cB}}$ & $23.00 \pm 0.21^{\mathrm{bB}}$ & $22.21 \pm 0.31^{\mathrm{bB}}$ \\
\hline & 8 & $38.13 \pm 0.15^{\mathrm{aC}}$ & $55.55 \pm 0.20^{\mathrm{fC}}$ & $53.24 \pm 0.28^{\mathrm{eC}}$ & $51.02 \pm 0.38^{\mathrm{dC}}$ & $48.01 \pm 0.22^{\mathrm{cC}}$ & $44.00 \pm 0.53^{\mathrm{bC}}$ \\
\hline & 12 & $42.24 \pm 0.18^{\mathrm{aD}}$ & $66.70 \pm 0.22^{\mathrm{fD}}$ & $62.20 \pm 0.32^{\mathrm{eD}}$ & $58.06 \pm 0.27^{\mathrm{dD}}$ & $54.96 \pm 0.23^{\mathrm{cD}}$ & $50.20 \pm 0.50^{\mathrm{bD}}$ \\
\hline \multirow[t]{4}{*}{ TOTOX } & 0 & $7.41 \pm 0.17^{\mathrm{bA}}$ & $7.03 \pm 0.19^{\mathrm{aA}}$ & $7.05 \pm 0.28^{\mathrm{aA}}$ & $6.93 \pm 0.18^{\mathrm{aA}}$ & $7.00 \pm 0.01^{\mathrm{aA}}$ & $7.29 \pm 0.27^{\mathrm{bA}}$ \\
\hline & 4 & $37.66 \pm 0.21^{\mathrm{aB}}$ & $63.42 \pm 0.25^{\mathrm{fB}}$ & $59.19 \pm 0.32^{\mathrm{eB}}$ & $52.61 \pm 0.15^{\mathrm{dB}}$ & $47.12 \pm 0.04^{\mathrm{cB}}$ & $44.43 \pm 0.30^{\mathrm{bB}}$ \\
\hline & 8 & $62.41 \pm 0.34^{\mathrm{aC}}$ & $106.33 \pm 2.17^{\mathrm{fC}}$ & $100.26 \pm 0.63^{\mathrm{eC}}$ & $94.84 \pm 1.57^{\mathrm{dD}}$ & $82.45 \pm 1.75^{\mathrm{cD}}$ & $75.54 \pm 1.90^{\mathrm{bD}}$ \\
\hline & 12 & $62.33 \pm 1.52^{\mathrm{aD}}$ & $102.66 \pm 0.85^{\mathrm{fD}}$ & $93.32 \pm 0.88^{\mathrm{eD}}$ & $87.08 \pm 0.31^{\mathrm{dC}}$ & $81.02 \pm 0.44^{\mathrm{cC}}$ & $74.20 \pm 0.75^{\mathrm{bC}}$ \\
\hline \multirow[t]{4}{*}{ TBA } & 0 & $2.24 \pm 0.01^{\mathrm{cA}}$ & $2.10 \pm 0.03^{\mathrm{aA}}$ & $2.11 \pm 0.02^{\mathrm{abA}}$ & $2.15 \pm 0.06^{\mathrm{abA}}$ & $2.19 \pm 0.05^{\mathrm{abA}}$ & $2.18 \pm 0.04^{\mathrm{abcA}}$ \\
\hline & 4 & $9.04 \pm 0.04^{\mathrm{aB}}$ & $17.00 \pm 0.13^{\mathrm{fB}}$ & $16.00 \pm 0.07^{\mathrm{eB}}$ & $15.89 \pm 0.27^{\mathrm{dB}}$ & $13.65 \pm 0.18^{\mathrm{cB}}$ & $12.00 \pm 0.12^{\mathrm{bB}}$ \\
\hline & 8 & $14.12 \pm 0.15^{\mathrm{aC}}$ & $28.48 \pm 0.14^{\mathrm{fC}}$ & $26.22 \pm 0.21^{\mathrm{eC}}$ & $24.78 \pm 0.23^{\mathrm{dC}}$ & $20.95 \pm 0.08^{\mathrm{cC}}$ & $18.91 \pm 0.27^{\mathrm{bC}}$ \\
\hline & 12 & $16.10 \pm 0.19^{\mathrm{aD}}$ & $33.39 \pm 0.15^{\mathrm{fD}}$ & $31.56 \pm 0.03^{\mathrm{eD}}$ & $28.52 \pm 0.19^{d \mathrm{D}}$ & $24.01 \pm 0.11^{\mathrm{cD}}$ & $20.00 \pm 0.54^{\mathrm{bD}}$ \\
\hline
\end{tabular}

Results are expressed as means \pm standard deviations of triplicate determinations. Values with different letters (lowercase) within a row for each parameter were significantly different $(p<0.05)$. Values with different letters (uppercase) within a column for each parameter were significantly different $(p<0.05)$. 
SO (25.39), and blend oils (RBO:SO): 10:90 (23.51), 20:80 (21.91), 40:60 (17.22) and 60:40 (15.77). For peroxides, the data confirmed the results obtained in early studies (Abdulkarim et al., 2007), with an increase in the peroxides until a maximum was reached, followed by a decrease in those compounds due to their reactions and degradations to other compounds. The addition of RBO to SO significantly $(p<0.05)$ slowed the increment of the concentration of hydroperoxides in SO. The $p$-anisidine value $(p-\mathrm{AV})$ is a more reliable and meaningful test compared to $\mathrm{PV}$, because it measures secondary oxidation products, which are more stable during the heating process (Al-Kahtani, 1991). At the end of $12 \mathrm{~h}$ heating, the maximum $p$-AV was detected in SO (66.70), whereas the lowest was in RBO (42.24) (Table 4). The significantly lower concentration of secondary reaction products as indicated by $p-\mathrm{AV}$ in blend oils compared to substrate SO might be due to the increasing of SFA or MUFA with decreasing of PUFA in SO, which are the primary targets of thermal oxidative reactions (Mohamed et al., 2014). Of the four blends, the blend RBO/SO (60:40) showed the lowest $p-\mathrm{AV}$, indicating that a further increase in the concentration of RBO in SO could be able to retard oxidative reactions. The TOTOX values in pure and blend oil samples increased with prolonged oxidation time (Table 4). Significant differences $(p<0.05)$ in TOTOX values in the samples were found after 12 $\mathrm{h}$ of the oxidation test. At the end of treatment, the highest value $(p<0.05)$ for TOTOX was found in SO (102.66) with the lowest obtained in SO incorporated with $60 \%$ RBO (74.20). In the present study, the levels of TOTOX values were not increased steadily with increasing heating time. The formation of secondary lipid peroxidation products as examined by means of the thiobarbituric acid (TBA) values showed significant increasing trends during thermal treatment for all samples (Table 4). At the end of thermal treatment, the sample containing RBO revealed a lower TBA $(20.00$ 31.56) compared to pure SO (33.39). A sharp rate of increment in $p$-AV or TBA values was noticed up to $8 \mathrm{~h}$ heating, followed by a decrease. This might have been possible due to the volatilization of secondary oxidation products or their further breakdown (Abuzaytoun and Shahidi, 2006). The lower concentration of degradative products detected in blend oils during heating is an indication of their good oxidative stability compared to pure SO. The nutritional contribution of minor components such as tocopherol, tocotrienols and oryzanol in RBO blends may have conferred this greater oxidative stability (Gulla and Waghray, 2011). Thus, the SO containing a higher amount of the RBO had the more inhibitory effect against oxidation due to the presence of minor components in RBO.

\section{Evaluation by FT-IR spectra}

Important spectral changes under the oxidative conditions at $170^{\circ} \mathrm{C}$ generated in substrate oils (RBO and $\mathrm{SO}$ ) and their blends on different heating hours are presented in Figure 1. In this study, a change in the intensity of some of the wavenumber regions was observed; only the regions that are related to certain oil oxidation products were evaluated. The spectra had absorption bands at wave numbers (Srivastava and Semwal, 2015; Guillen and Cabo, 1997): $3009 \mathrm{~cm}^{-1}$ [stretching $=\mathrm{C}-\mathrm{H}(\mathrm{cis})], 2928 \mathrm{~cm}^{-1}$ [asymmetric stretching $\left.-\mathrm{C}-\mathrm{H}\left(-\mathrm{CH}_{2}\right)\right], \quad 2854 \mathrm{~cm}^{-1}$ [symmetric stretching $-\mathrm{C}-\mathrm{H}\left(-\mathrm{CH}_{2}\right)$ ], $1745 \mathrm{~cm}^{-1}$ [stretching $-\mathrm{C}=\mathrm{O}$ ], $1466 \mathrm{~cm}^{-1}$ [bending $\left.-\mathrm{C}-\mathrm{H}\left(\mathrm{CH}_{2}\right)\right], 1161$, and $1099 \mathrm{~cm}^{-1}$ [stretching $-\mathrm{C}-\mathrm{O}]$.

The intensity (absorbances) at $3009 \mathrm{~cm}^{-1}$ (shoulder) increased with increased heating time for the formation of free radicals, which caused an initiation of primary oxidation reactions of unsaturated fatty acids. This reaction resulted in primary oxidation products having cis and conjugated double bonds, whichalso happened in the case of the autoxidation of oleic and linoleic acids (Belitz and Grosch, 1999; Moharam and Abbas, 2010). The intensities of the band at $2928 \mathrm{~cm}^{-1}$ and $2854 \mathrm{~cm}^{-1}$ were increased as oxidation progressed; this could be related to the surrounding chemical changes as a result of the eventual oxidation process (Liang et al., 2013). Vlachos et al. (2006) revealed that the absorbance intensity at $2854 \mathrm{~cm}^{-1}$ increased, whereas the band at $2925 \mathrm{~cm}^{-1}$ reduced its absorbance and increased its width during the process of heating corn oil. An increase in peak intensity at $1745 \mathrm{~cm}^{-1}$ was found during heating; the higher the intensities at $1745 \mathrm{~cm}^{-1}$, the more carbonylic compounds present, which are formed by hydroperoxide decomposition (Rohman, 2017). Valdés et al. (2015) identified the increment in absorbance intensity at 2856 and $1745 \mathrm{~cm}^{-1}$ during accelerated oxidation of blanched, roasted or fried almonds. The intensity of the band at 

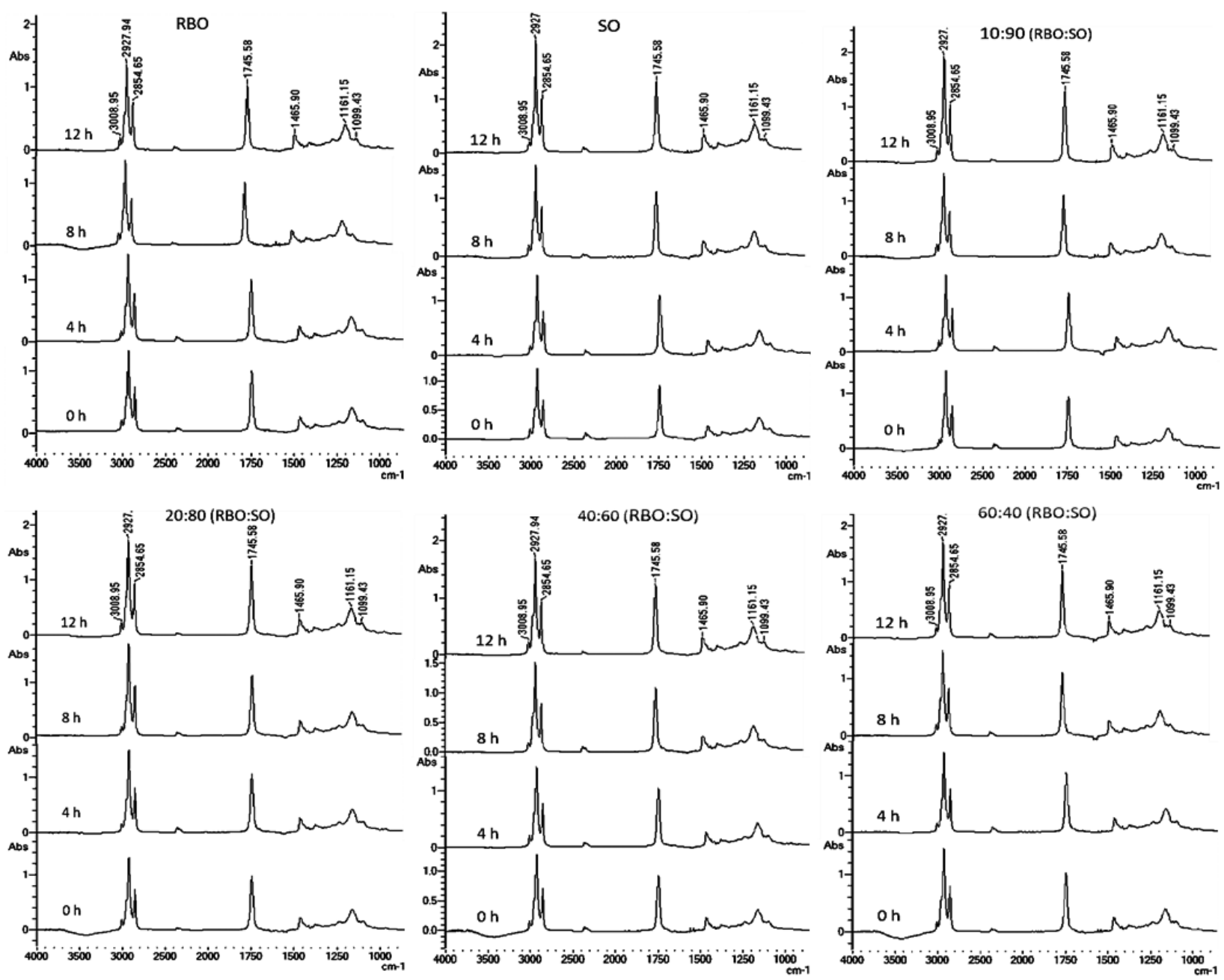

Fig. 1. FT-IR spectra of rice bran oil, soybean oil, and their blends during heating

1466 tends to increase with the oxidative treatment. A similar result was reached by Valdés et al. (2015) when investigating the oxidative stability of almonds by ATR-FTIR. The intensity of a weak band near $1161 \mathrm{~cm}^{-1}$ closely related to the proportion in the sample of saturated acyl groups (Guillen and Cabo, 1997); it undergoes similar changes during the oxidation process and increases its intensity. Liang et al. (2013) observed a similar trend for the same band in the case of heating walnut oils. The present study demonstrates that the absorbance value was affected by the heating conditions employed. Of course, in most cases, the changes in absorbance were lower in the sample incorporated with RBO compared to the substrate SO throughout the oxidation process. This observation clearly shows that RBO protected the SO sample effectively from oxidative decomposition during heating at $170^{\circ} \mathrm{C}$. The above data from FTIR lead to the same conclusions as changes in the physicochemical properties as depicted earlier.

\section{CONCLUSION}

In conclusion, the changes observed in oxidative parameters, FAC, and FTIR spectral data at $12 \mathrm{~h}$ of oxidative treatment were more evident for pure $\mathrm{SO}$, indicating a greater extent of oxidation compared to those observed in blend ones. Therefore, the present results 
clearly indicate that partial replacement of soybean oil with RBO can significantly improve the thermal stability of SO. After $12 \mathrm{~h}$ of heating, the difference in the quality of SO in the presence of $60 \% \mathrm{RBO}$ was remarkable compared to the remeaning blends. Blending SO with RBO is encouraged in order to modify the fatty acid composition of the oil, because SO is rich in PUFA, while RBO is rich in SFA and MUFA, in addition to bioactive phytochemicals. This study will help the oil-producing industry to find the most economically viable oil blends for cooking purposes, with the maximum nutrition and desirable physicochemical properties.

\section{REFERENCES}

Abdulkarim, S., Long, K., Lai, O. M., Muhammad, S. K. S., Ghazali, H. M. (2007). Frying quality and stability of high-oleic Moringa oleifera seed oil in comparison with other vegetable oils. Food Chem., 105, 1382-1389. http://dx.doi.org/10.1016/j.foodchem.2007.05.013

Abuzaytoun, R., Shahidi, F. (2006). Oxidative stability of flax and hemp oils. J. Am. Oil Chem. Soc., 83, 855-861. http://dx.doi.org10.1007/s11746-006-5037-7

Ali, M. A., Nouruddeen, Z. B., Muhamad, I. I., Latip, R. A., Othman N. H., Mahmood, N. A. N. (2013). Impact of palm olein addition on the thermooxidative degradation of canola oil during frying. Chiang Mai J. Sci., 40, 643-655.

Ali, M. A., Nouruddeen, Z. B., Muhamad, I. I., Latip, R. A., Othman, N. H. (2014). Effect of palm olein addition on the quality characteristics of sunflower oil during deep fat frying. Acta Aliment., 43, 288-296. http://dx.doi. org/10.1556/AAlim.43.2014.2.13

Al-Kahtani, H. (1991). Survey of quality of used frying oils from restaurants. J. Am. Oil Chem. Soc., 68, 857-862. http://dx.doi.org/10.1007/BF02660602

AOCS (1987). Official methods and recommended practices of the American Oil Chemists' Society. Champaign: AOCS.

Arslan, F. N., Kara, H., Talpur, M. Y., Sherazi, S. T. H. (2015). A chemometric approach to assess the frying stability of cottonseed oil blends during deep-frying process: fatty acid composition and tocopherol analyses. Int. J Food Prop., 18, 2776-2790. http://dx.doi.org/10.1 080/10942912.2014.959131

Belitz, H., Grosch, W. (1999). Food chemistry (2nd ed.). Berlin, Heidelberg: Springer.
Chotimarkorn, C., Silalai, N. (2008) Oxidative stability of fried dough from rice flour containing rice bran powder during storage. LWT - Food Sci. Technol., 41, 561-568. http://dx.doi.org/10.1016/j.lwt.2007.05.005

Choudhary, M., Grover, K., Kaur, G. (2015). Development of rice bran oil blends for quality improvement. Food Chem., 173, 770-777. http://dx.doi.org/10.1016/j. foodchem.2014.10.051

Das, A. B., Goud, V. V., Das, C. (2018). Extraction and characterization of phenolic content from purple and black rice (Oryza sativa L.) bran and its antioxidant activity. Food Measur., 12, 332-345. http://dx.doi.org/10.1007/ s11694-017-9645-8

De Marco, E., Savarese, M., Parisini, C., Battimo, I., Falco, S., Sacchi, R. (2007). Frying performance of a sunflower/palm oil blend in comparison with pure palm oil. Eur. J. Lipid Sci. Technol., 109, 237-246. http://dx.doi. org/10.1002/ejlt.200600192

Fernández-Cedi, L. N., Enríquez-Fernández, B. E., Yañez, L. Á. C., Sosa-Morales, M. E. (2012). Performance of palm olein and soybean oil during the frying of french fries and its effect on the characteristics of the fried product. J. Culin. Sci. Technol., 10, 211-222. http://dx.doi.or $\mathrm{g} / 10.1080 / 15428052.2012 .706125$

Guillen, M. D., Cabo, N. (1997). Characterization of edible oils and lard by fourier transform infrared spectroscopy. Relationships between composition and frequency of concrete bands in the fingerprint region. J. Am. Oil Chem. Soc., 74, 1281-1286. http://dx.doi.org/10.1007/ s11746-997-0058-4

Gulla, S., Waghray, K. (2011). Effect of storage on physicochemical characteristics and fatty acid composition of selected oil blends. J. Life Sci., 3, 35-46. http://dx.doi. org/10.1080/09751270.2011.11885167

Ivanov, D. S., Lević, J. D., Sredanović, S. A. (2010). Fatty acid composition of various soybean products. Food Feed Res., 37, 65-70.

Lakkakula, N. R., Lima, M., Walker, T. (2004). Rice bran stabilization and rice bran oil extraction using ohmic heating. Biores. Technol., 92, 157-161. http://dx.doi. org/10.1016/j.biortech.2003.08.010

Lee, Y. R., Woo, K. S., Kim, K. J., Son, J. R., Jeong, J. R. (2007). Antioxidant activity of ethanol extracts from germinated specialty rough rice. Food Sci. Biotechnol., $16,765-770$.

Liang, P., Chen, C., Zhao, S., Ge, F., Liu, D., Liu, B., ..., Xiong, X. (2013). Application of fourier transform infrared spectroscopy for the oxidation and peroxide value evaluation in virgin walnut oil. J. Spectrosc., 2013, 1-5. http://dx.doi.org/10.1155/2013/138728 
Ali, M. A., Islam, M. A., Othman, N. H., Noor, A. M., Ibrahim, M. (2019). Effect of rice bran oil addition on the oxidative degradation and fatty acid composition of soybean oil during heating. Acta Sci. Pol. Technol. Aliment., 18(4), 427-438. http://dx.doi.org/10.17306/ J.AFS.2019.0964

Mezouari, S., Eichner, K. (2007). Comparative study on the stability of crude and refined rice bran oil during long-term storage at room temperature. Eur. J. Lipid Sci. Technol., 109, 198-205. http://dx.doi.org/10.1002/ ejlt.200600154

Mishra, R., Sharma, H. K. (2014). Effect of frying conditions on the physico-chemical properties of rice bran oil and its blended oil. J. Food Sci. Technol., 51, 1076 1084. http://dx.doi.org/10.1007/s13197-011-0602-y

Mohamed, K. M., Elsanhoty, R. M., Hassanien, M. F. R. (2014). Improving thermal stability of high linoleic corn oil by blending with black cumin and coriander oils. Int. J. Food Proper., 17, 500-510. http://dx.doi.org/10.1080/ 10942912.2012 .654560

Moharam, M. A., Abbas, L. M. (2010). A study on the effect of microwave heating on the properties of edible oils using FTIR spectroscopy. Afr. J. Microbiol. Res., 4, 1921-1927.

Mostafa, R. A., Moharram, Y. G., Attia, R. S., El-Sharnouby, S. A. (2013). Formulation and characterization of vegetable oil blends rich in omega-3 fatty acids. Emir. J. Food Agric., 25, 426-433. http://dx.doi.org/10.9755/ ejfa.v25i6.12091

Nederal, S., Skevin, D., Kraljic, K., Obranovic, M., Papesa, S., Bataljaku, A. (2012). Chemical composition and oxidative stability of roasted and cold pressed pumpkin seed oils. J. Am. Oil Chem. Soc., 89, 1763-1770. http:// dx.doi.org/10.1007/s11746-012-2076-0

Normand, L., Eskin, N. A. M., Przybylski, R. (2001). Effects of tocopherols on the frying stability of regular and modified canola oils. J. Am. Oil Chem. Soc., 78, 369-373. http://dx.doi.org/10.1007/s11746-001-0270-7

Perez-Ternero, C., Sotomayor, M. A., Herrera, M. D. (2017). Contribution of ferulic acid, g-oryzanol and tocotrienols to the cardiometabolic protective effects of rice bran. J. Funct. Food, 32, 58-71. http://dx.doi.org/10.1016/j. jff.2017.02.014

Pestana, V. R., Zambiazi, R. C., Mendonça, C. R. B., Bruscatto, M. H., Lerma-García, M. J., Ramis-Ramos, G. (2008). Quality changes and tocopherols and $\gamma$-orizanol concentrations in rice bran oil during the refining process. J. Am. Oil Chem. Soc., 85, 1013-1019. http:// dx.doi.org/10.1007/s11746-008-1300-4

PORIM (1995). PORIM Test Methods. Palm Oil Research Institute of Malaysia Ministry of Primary Industries, Malaysia.

Ribeiro, A. P. B., Moura, J. M. L. N., Grimaldi, R., Gonçalves, L. A. G. (2007). Interesterificação química: alternativa para obtenção de gorduras zero trans. Quimica Nova, 30, 1295-1300. http://dx.doi. org/10.1590/S0100-40422007000500043

Rohman, A. (2017). Infrared spectroscopy for quantitative analysis and oil parameters of olive oil and virgin coconut oil: A review. Int. J. Food Prop., 20, 1447-1456. http://dx.doi.org/10.1080/10942912.2016.1213742

Rohman, A., Che Man, Y. B., Ismail, A., Hashim, P. (2011). Monitoring the oxidative stability of virgin coconut oil during oven test using chemical indexes and FTIR spectroscopy. Intr. Food Res. J., 18, 303-310.

Rudzińska, M., Hassanein, M. M. M., Abdel-Razek, A. G., Kmiecik, D., Siger, A., Ratusz, K. (2018). Influence of composition on degradation during repeated deep-fat frying of binary and ternary blends of palm, sunflower and soybean oils with health-optimised saturated-to-unsaturated fatty acid ratios. Int. J. Food Sci. Technol., 53, 1021-1029. http://dx.doi.org/10.1111/ijfs.13678

Rudzińska, M., Hassanein, M. M. M., Abdel-Razek, A. G., Ratusz, K., Siger, A. (2016). Blends of rapeseed oil with black cumin and rice bran oils for increasing the oxidative stability. J. Food Sci. Technol., 53, 1055-1062. http://dx.doi.org/10.1007/s13197-015-2140-5

Semwal, A. D., Arya, S. S. (2001). Studies on the stability of some edible oils and their blends during storage. J. Food Sci. Technol., 38, 515-518.

Shahidi, F. (2005). Bailey's industrial oil and fat products. Hoboken: John Wiley.

Shao, D., Venkitasamy, C., Li, X., Pan, Z., Shi, J., Wang, B., ..., McHugh, T. H. (2015). Thermal and storage characteristics of tomato seed oil. LWT - Food Sci. Technol., 63, 191-197. http://dx.doi.org/10.1016/j.lwt.2015.03.010

Sharma, H. K., Kaur, B., Sarkar, B. C., Singh, C. (2006). Thermal behavior of pure rice bran oil, sunflower oil and their model blends during deep fat frying. Grasas Y Aceites, 57, 376-381. http://dx.doi.org/10.3989/ gya.2006.v57.i4.62

Sohail, M., Rakha, A., Butt, M. S., Iqbal, M. J., Rashid, S. (2017). Rice bran nutraceutics: A comprehensive review. Crit. Rev. Food Sci. Nutr., 57, 3771-3780. http:// dx.doi.org/10.1080/10408398.2016.1164120

Srivastava, Y., Semwal, A. D. (2015). A study on monitoring of frying performance and oxidative stability of virgin coconut oil (VCO) during continuous/prolonged deep fat frying process using chemical and FTIR spectroscopy. J. Food Sci. Technol., 52, 984-991. http://dx.doi. org/10.1007/s13197-013-1078-8

Srivastava, Y., Semwal, A. D., Sajeevkumar, V. A., Sharma, G. K. (2017). Melting, crystallization and storage stability of virgin coconut oil and its blends by differential scanning calorimetry (DSC) and Fourier transform 
Ali, M. A., Islam, M. A., Othman, N. H., Noor, A. M., Ibrahim, M. (2019). Effect of rice bran oil addition on the oxidative degradation and fatty acid composition of soybean oil during heating. Acta Sci. Pol. Technol. Aliment., 18(4), 427-438. http://dx.doi.org/10.17306/ J.AFS.2019.0964

infrared spectroscopy (FTIR). J. Food Sci. Technol., 54, 45-54. http://dx.doi.org/10.1007/s13197-016-2427-1

Valdés, A., Beltrán, A., Karabagias, I., Badeka, A., Kontominas, M. G., Garrigós, M. C. (2015). Monitoring the oxidative stability and volatiles in blanched, roasted and fried almonds under normal and accelerated storage conditions by DSC, thermogravimetric analysis and ATR-FTIR. Eur. J. Lipid Sci. Technol., 117, 1199-1213. http://dx.doi.org/10.1002/ejlt.201400384

Vlachos, N., Skopelitis, Y., Psaroudaki, M., Konstantinidou, V., Chatzilazarou, A., Tegou, E. (2006). Applications of Fourier transform-infrared spectroscopy to edible oils.
Anal. Chim. Acta, 573-574, 459-465. http://dx.doi. org/10.1016/j.aca.2006.05.034

Wai, W. T., Saad, B., Lim, B. P. (2009). Determination of TOTOX value in palm oleins using a FI-potentiometric analyzer. Food Chem., 113, 285-290. http://dx.doi. org/10.1016/j.foodchem.2008.06.082

Yoshida, H., Takagi, S., Mitsuhashi, S. (1999). Tocopherol distribution and oxidative stability of oils prepared from the hypocotyl of soybeans roasted in microwave oven. J. Am. Oil Chem. Soc., 6, 915-920. http://dx.doi. org/10.1007/s11746-999-0106-3 